\title{
INVESTIGASI PEMAHAMAN KONSEPTUAL CALON GURU TERHADAP SEGIEMPAT
}

\author{
Latief Sahidin ${ }^{1}$, Ikman $^{2}$ \\ Jurusan Pendidikan Matematika ${ }^{1,2}$, Fakultas Keguruan dan Ilmu Pendidikan ${ }^{1,2}$, \\ Universitas Halu Oleo ${ }^{1,2}$ \\ latief.sahidin@uho.ac.id ${ }^{1}$,ikman@uho.ac.id ${ }^{2}$
}

\begin{abstract}
Abstrak
Segiempat sebagai materi geometri sekolah sangat penting untuk dipahami oleh guru matematika. Materi segiempat yang esensial perlu dikuasai dan dimiliki oleh guru matematika yaitu definisi dan klasifikasi segiempat. Tujuan penelitian ini adalah untuk mengetahui bagaimana tingkat pemahaman calon guru matematika dalam mengungkapkan definisi dan mengklasifikasi segiempat. Jenis penelitian ini merupakan penelitian deskriptif-kualitatif. Data penelitian diperoleh dengan bantuan vignette dianalisis dengan metode analisis isi. Data yang diperoleh selanjutnya direduksi, dikode, dikategori dan disimpulkan. Penelitian ini dilakukan dengan subjek calon guru matematika yang belajar di Pendidikan Profesi Guru Universitas Halu Oleo pada tahun akademik 2018, berjumlah 29 mahasiswa calon guru (8 laki-laki \& 21 perempuan) berusia antara 23 - 28 tahun. Dari data diperoleh, ditemukan bahwa sebagian besar calon guru matematika cukup baik dalam mendefinisikan trapesium, persegi dan belahketupat tetapi mengalami kesulitan dalam mendefinisikan layang-layang, jajargenjang, persegipanjang secara ekonomis. Sebagian besar calon guru cukup baik dalam mengklasifikasi segiempat secara inklusif atau secara eksklusif, tetapi ada beberapa yang mengalami kesulitan mengklasifikasi persegi dan belahketupat dengan tepat. Sebagian besar calon guru masih berada pada tingkat developing-conceptual pemahaman konseptualnya terhadap segiempat.
\end{abstract}

Kata Kunci: segiempat, pemahaman konseptual, calon guru matematika.

\section{A. Pendahuluan}

Permasalahan calon guru dalam menggunakan pengetahuan matematika telah dikaji dan menjadi perhatian serius dalam penelitian pendidikan matematika saat ini. Ball et al. (2001) dalam penelitiannya mengungkapkan bahwa calon guru pendidikan dasar dan menengah masih memiliki kelemahan dalam memahami konsep-konsep dasar dalam matematika. Peneliti lain juga menunjukkan bahwa pengetahuan konten guru dan calon guru sekolah menengah dalam geometri rendah (Fuys, Geddes \& Tischler, 1988; Mayberry, 1983). Ma'rufi (2016); Hershkowitz \& Vinner (1984) menemukan bahwa guru dan calon guru kurang memiliki pengetahuan geometri dasar, keterampilan dan kemampuan berpikir analitis. 
Barrantes dan Blanco (2006) menyatakan bahwa sebagian besar calon guru memiliki pengetahuan tentang geometri yang lemah. Fujita \& Jones (2007) juga menyatakan bahwa situasi ini merupakan masalah penting dan menciptakan kesenjangan antara konsep dan definisi.

Terdapat pula studi yang menekankan kurangnya pengetahuan matematika dalam pengajaran di tingkat sekolah dasar. De Villiers (1998) menyatakan bahwa guru mengalami masalah berdasarkan pengetahuan matematika dan keterampilan, terutama selama mengajar mata pelajaran geometri sangat berbeda dari segiempat yang sama mereka ajarkan dalam materi di sekolah. Namun belum banyak penelitian yang mengungkap sejauhmana pemahaman konseptual calon guru dalam mendefinisikan dan mengklasifikasi segiempat.

Materi segiempat adalah salah satu materi yang dipelajari dan diajarkan secara luas di sekolah dasar, sekolah menengah dan pendidikan tinggi. Khususnya di sekolah menengah, konsep segiempat yang diajarkan terbatas pada segiempat konveks. Meskipun guru tidak mengalami kesulitan dalam mengenalkan konsep segiempat, namun mereka mengalami kesulitan dalam memahami dan menafsirkan segiempat yang mereka gunakan dalam pembelajaran secara konseptual. Padahal, pengembangan pengetahuan dan keterampilan pada pemahaman konseptual dikenal sebagai tugas penting bagi guru matematika (Chick, 2003). Hal ini karena mengajar pemahaman konsep membutuhkan pemahaman yang berhubungan dengan beberapa pengetahuan. Sahidin (2019a) menyebutkan dua jenis pengetahuan untuk pemahaman konseptual: pengetahuan kategori dan pengetahuan klasifikasi.

Untuk alasan ini, adalah sangat penting bagi calon guru untuk memiliki pengetahuan matematika yang cukup saat mengajar konsep-konsep ini. Kami menemukan beberapa studi dalam literatur dimana guru dan calon guru bingung dalam membuat hubungan antara segiempat (Fujita, 2008; Okazaki \& Fujita, 2007). Dalam sebuah studi dengan calon guru sekolah dasar, Fujita dan Jones (2006) melaporkan bahwa calon guru tampaknya tidak memiliki pemahaman yang baik tentang hubungan hirarkis antara segiempat. Misalnya, pemahaman calon guru, "persegipanjang" sebagai kasus khusus dari "persegi” dan calon guru dapat menggambar yang benar persegi tetapi didefinisikan tidak benar. Selanjutnya, 
bahkan setelah dua tahun pendidikan, pemahaman calon guru tampaknya tidak meningkat.

Han (2003) menemukan bahwa calon guru tidak memiliki pemahaman yang baik tentang segiempat. Fujita dan Jones (2006) dalam penelitian mereka untuk menentukan persepsi guru sekolah dasar trainee mengenai jajarangenjang, menunjukkan bahwa hanya sebagian kecil 105 calon belajar di tahun kedua di universitas memiliki pengetahuan tentang jajargenjang. Sukses mengajar geometri tergantung pada pengetahuan geometri guru memiliki dan/kemampuannya untuk mengajarkannya dengan cara yang efektif. Selain itu, fakta bahwa pemahaman geometri secara mendalam oleh para guru akan membantu siswa mengatasi kesulitan yang mereka hadapi (Günhan, 2014).

Ball (1988), pikiran guru tentang matematika ditemukan pada tahun-tahun ketika mereka adalah mahasiswa di universitas dan penataan proses ini terus berlanjut dalam perjalanan karir guru. Langkah yang paling penting untuk dapat memberikan kontribusi untuk proses ini adalah penataan dalam lembaga yang melatih para guru. Selain itu, calon guru matematika ketika mereka menjadi mahasiswa harus mampu memahami pengetahuan konsep dan mampu menghubungkan antar konsep dengan benar.

Konsep segiempat dipilih dalam penelitian ini karena merupakan salah satu konsep yang paling dasar dalam geometri, dimana siswa masih mengalami kesalahpahaman dan kesulitan (Clements, 1999; Currie \& Pegg, 1998; Monaghan, 2000; Wu \& Ma, 2005). Monaghan (2000) mencatat bahwa banyak kesalahan siswa dalam memahami sifat-sifat segiempat. Segiempat yang diajarkan baik di pendidikan dasar dan menengah terbatas pada jenis segiempat konveks. Bahkan, segiempat konveks didefinisikan dalam enam kategori dalam kurikulum SMP: jajargenjang, trapesium, layang-layang, persegipanjang, belahketupat, dan persegi (Clements, 1998). Selain itu, jenis segiempat sering dihadapi siswa dalam kehidupan sehari-hari.

Materi segiempat yang dipelajari di sekolah dasar dan menengah meliputi: jajargenjang, trapesium, layang-layang, persegipanjang, belahketupat, dan persegi. Agar para guru dapat mengajarkan materi segiempat tersebut, mereka pertama kali harus memiliki pemahaman konseptual. Chapman (2015) menguraikan bahwa 
pemahaman konseptual adalah pemahaman tentang konsep-konsep, prosedurprosedur dan hubungan-hubungan matematika. Oleh karena itu, pertanyaanpertanyaan seperti "apakah persegi adalah persegipanjang? Bagaimana hubungan antara persegi dan persegipanjang ini secara hirarkis?", harus dipertimbangkan oleh guru. Tiga faktor penting dalam memahami konsep segiempat adalah memahami definisi dari segiempat, mengklasifikasi segiempat dan hubungan antara segiempat (Türnüklü et al. 2013; Fujita, 2012).

Dalam sebuah studi oleh McCammon (2018); Ulger \& Broutin (2017); Günhan (2014) disimpulkan bahwa definisi dan klasifikasi saling terkait dan klasifikasi segiempat tidak bisa secara akurat diungkapkan tanpa mengetahui definisi segiempat; selain itu, perlunya keterampilan memahami definisi untuk sukses dalam mengajarkan segiempat. Dalam rangka untuk memahami segiempat secara konseptual, guru sangat penting untuk memahami dan mengklasifikasikan hubungan antara segiempat. Dalam mengklasifikasi hubungan antara segiempat, penting untuk dapat melihat hubungan hirarkis antara segiempat; hal itu karena definisi sangat penting dalam matematika karena dapat bermanfaat sebagai titik awal untuk argumen deduktif dalam sistem aksiomatik (Govender \& Villiers, 2002).

Tujuan dari penelitian ini adalah untuk menyelidiki pemahaman konseptual calon guru mengenai segiempat tentang definisi klasifikasi segiempat, dan tingkat pemahaman konseptual. Oleh karena itu, jawaban yang dicari untuk pertanyaanpertanyaan berikut: (1) Bagaimanakah calon guru dalam mendefinisikan segiempat?; (2) Bagaimanakah calon guru dalam mengklasifikasikan segiempat?; dan (3) Bagaimanakah tingkat pemahaman konseptual calon guru terhadap materi segiempat?.

\section{B. Metode Penelitian}

Dalam penelitian ini, digunakan analisis isi yang merupakan salah satu metode penelitian kualitatif. Untuk alasan ini, analisis vignette digunakan untuk memperoleh data penelitian. Menurut Çepni (2018), analisis isi diperlukan untuk menganalisis secara mendalam dari data yang dikumpulkan dan memungkinkan untuk menjelaskan konstruk yang ada. 
Metode yang digunakan dalam penelitian ini adalah purposive sampling yang digunakan dalam penelitian ini. Peserta dipilih di antara individu dengan kualifikasi tertentu (Büyüköztürk, Kilic-Çakmak, Erkan-Akgün, Karadeniz \& Demirel, 2009). Dalam pemilihan calon guru matematika dipilih sebagai kriteria utama. Peserta rata-rata memiliki usia 25 tahun, paling rendah berusia 23 tahun sampai paling tinggi berusia 28 tahun. Berdasarkan jenis kelamin, 21 orang (72.4\%) perempuan (P) dan 8 orang (27.6\%) laki-laki (L). Peserta telah diseleksi melalui tes masuk yang dijaring secara ketat dan terbuka.

Tabel 1. Deskripsi Subjek penelitian

\begin{tabular}{lrrlcr}
\hline Kode & Gender & Usia & Kode & Gender & Usia \\
\hline S1 & P & 26 & S16 & P & 25 \\
\hline S2 & L & 23 & S17 & P & 24 \\
\hline S3 & P & 24 & S18 & P & 24 \\
\hline S4 & L & 24 & S19 & P & 25 \\
\hline S5 & P & 25 & S20 & P & 24 \\
\hline S6 & P & 23 & S21 & P & 25 \\
\hline S7 & L & 23 & S22 & L & 23 \\
\hline S8 & P & 28 & S23 & P & 26 \\
\hline S9 & L & 25 & S24 & P & 24 \\
\hline S10 & L & 25 & S25 & P & 24 \\
\hline S11 & P & 24 & S26 & P & 25 \\
\hline S12 & L & 24 & S27 & P & 27 \\
\hline S13 & P & 26 & S28 & P & 24 \\
\hline S14 & P & 27 & S29 & P & 28 \\
\hline S15 & L & 26 & & & \\
\hline
\end{tabular}

Vignette yang dikembangkan oleh peneliti berfungsi sebagai alat pengumpul data. Vignette yang disiapkan telah divalidasi oleh dua ahli di bidang geometri dan diselesaikan dengan membuat koreksi yang diperlukan.

Vignette:

1. Sebagai seorang guru matematika SMP Anda harus mengajarkan segiempat. Segiempat yang dimaksud yaitu: jajargenjang, persegipanjang, belahketupat, persegi, trapesium, dan layang-layang. Menurut pengetahuan yang Anda miliki, tuliskan definisi jajargenjang, persegipanjang, belahketupat, persegi, trapesium, layang-layang. 
2. Buatlah klasifikasi (peta konsep) sendiri yang menggambarkan hubungan antara jajargenjang, persegipanjang, belahketupat, persegi, trapesium, dan layang-layang!

Mahasiswa calon guru diberi waktu 90 menit dan diminta untuk menjawab vignette dengan menuliskan jawaban dengan jelas. Dalam penelitian ini, peneliti menggunakan metode analisis isi untuk mengungkapkan pemahaman konseptual subjek yang diteliti (Yildirim dan Simsek, 2008). Berdasarkan metode ini, analisis isi digunakan untuk menganalisis data, melakukan pengkodean (koding). Dari data yang diperoleh, selanjutnya dibagi dalam dua konstruk yaitu konstruk mendefinisikan segiempat dan mengklasifikasikan segiempat.

\section{Hasil Dan Pembahasan}

Dalam analisis isi untuk vignette pertama, jawaban dari subjek untuk definisi jajargenjang, persegipanjang, belahketupat, persegi, trapesium, layang-layang, diperiksa secara individual dan dibagi dalam empat kategori untuk konstruk definisi segiempat yaitu: definisi ekonomis, defenisi tidak ekonomis, definisi salah dan tidak menjawab. Nilai-nilai frekuensi dari kode yang diberikan disajikan dalam Tabel 2 berikut.

Tabel 2. Deskripsi hasil vignette "definisi jajargenjang, persegipanjang, belahketupat, persegi, trapesium, layang-layang"

\begin{tabular}{lcccc}
\hline \multicolumn{1}{c}{ Kode } & f & $\%$ & Kategori & Konstruk \\
\hline $\begin{array}{l}\text { Segiempat yang memiliki sepasang sisi berhadapan } \\
\text { sejajar dan sama panjang (S8) }\end{array}$ & 1 & 3.4 & Ekonomis & $\begin{array}{c}\text { Definisi } \\
\text { jajargen } \\
\text { jang }\end{array}$ \\
\hline $\begin{array}{l}\text { Segiempat yang pasangan sisi berhadapan,sejajar } \\
\text { sama panjang, dan sudut yang berhadapan sama } \\
(\mathrm{S} 1,2,4,10,12,17,19,20,21,22,25,28)\end{array}$ & 12 & 41.4 & $\begin{array}{c}\text { Tidak } \\
\text { ekonomis }\end{array}$ & \\
$\begin{array}{l}\text { Segiempat yang memiliki dua pasang sisi sejajar } \\
\text { dan sama panjang (S3, 6, 11, 23, 24, 28) }\end{array}$ & 6 & 20.7 & \\
$\begin{array}{l}\text { Segiempat yang dua pasang sisi sejajar dan sudut } \\
\text { yang berhadapan sama besar (S7, 9, 15, 18) }\end{array}$ & 4 & 13.8 & \\
$\begin{array}{l}\text { Segiempat yang dibentuk oleh dua pasang sisi yang } \\
\text { sama panjang dan sejajar, dan memiliki dua pasang }\end{array}$ & & & & \\
\hline
\end{tabular}




\begin{tabular}{|c|c|c|c|c|}
\hline Kode & $\mathrm{f}$ & $\%$ & Kategori & Konstruk \\
\hline $\begin{array}{l}\text { Segiempat yang memiliki sepasang sisi sama panjang } \\
\text { dan sejajar (S5) } \\
\text { Segiempat yang memiliki dua pasang sudut sama } \\
\text { besar (S12) } \\
\text { Segiempat yang dibentuk oleh dua pasang rusuk yang } \\
\text { sama panjang dan sejajar dengan pasangannya, } \\
\text { memiliki empat sudut yang bukan siku-siku (S14, 26, } \\
\text { 27) }\end{array}$ & $\begin{array}{l}1 \\
1\end{array}$ & $\begin{array}{l}3.4 \\
3.4\end{array}$ & Salah & \\
\hline Tidak ada Jawaban & 0 & 0 & $\begin{array}{l}\text { Tidak ada } \\
\text { iawaban }\end{array}$ & \\
\hline $\begin{array}{l}\text { Segiempat yang memiliki sepasang sisi sejajar } \\
(\mathrm{S} 2,3,5,6,7,9,10,11,12,15,21,24,25) \\
\text { Segiempat yang memiliki tepat sepasang sisi } \\
\text { berhadapan sejajar ( } 44,8,13,17,23,28) \\
\text { Segiempat dengan minimal satu pasang sisi } \\
\text { yang sejajar (S22) }\end{array}$ & 13 & $\begin{array}{c}44.8 \\
20.7 \\
3.4\end{array}$ & Ekonomis & $\begin{array}{l}\text { Definisi } \\
\text { trapesiu } \\
\mathrm{m}\end{array}$ \\
\hline $\begin{array}{l}\text { Segiempat yang memiliki sepasang sisi yang } \\
\text { berhadapan sejajar dan tidak sama panjang serta } \\
\text { memiliki sisi yang lain tetapi tidak sejajar (S14, } \\
26,29) \\
\text { Segiempat yang memiliki sepasang sisi yang } \\
\text { berhadapan sejajar dan jumlah sudutnya } 360 \\
\text { derajat }(\mathrm{S} 18,19)\end{array}$ & 3 & $\begin{array}{l}10.3 \\
6.9\end{array}$ & $\begin{array}{c}\text { Tidak } \\
\text { ekonomis }\end{array}$ & \\
\hline $\begin{array}{l}\text { Segiempat yang memiliki sepasang sisi yang } \\
\text { sejajar dan tidak sama panjang }(\mathrm{S} 1,2) \\
\text { Bangun datar dua dimensi yang dibentuk oleh } \\
\text { sepasang sisi yang sejajar dan sisi lainnya sama } \\
\text { panjang, diagonal-diagonalnya sama panjang } \\
\text { dan sepasang sudut siku-siku (S16) } \\
\text { Segiempat yang sepasang sisi yang berhadapan } \\
\text { sama panjang (S20) }\end{array}$ & 1 & 3.4 & Salah & \\
\hline Tidak ada Jawaban & 0 & 0 & $\begin{array}{l}\text { Tidak ada } \\
\text { jawaban }\end{array}$ & \\
\hline- & 0 & 0 & Ekonomis & \\
\hline $\begin{array}{l}\text { Segiempat yang dua pasang sisinya yang berdekatan } \\
\text { sama panjang dan sepasang sudut yang berhadapan } \\
\text { sama besar yang lebih dari } 90 \text { derajat }(\mathrm{S} 1,9,19) \\
\text { Bangun datar dua dimensi yang dibentuk oleh dua } \\
\text { pasang sisi yang sama panjang, sepasang sudut } \\
\text { berhadapan sama besar dan dua diagonal yang } \\
\text { saling tegak lurus dan tidak sama panjang }(\mathrm{S} 16,28) \\
\text { Segiempat yang memiliki dua pasang sisi sama } \\
\text { panjang dan kedua diagonalnya saling tegak lurus (S4, } \\
7,8,18,20,24,25)\end{array}$ & 2 & 6.9 & $\begin{array}{c}\text { Tidak } \\
\text { ekonomis }\end{array}$ & $\begin{array}{c}\text { Definisi } \\
\text { layang- } \\
\text { layang }\end{array}$ \\
\hline
\end{tabular}




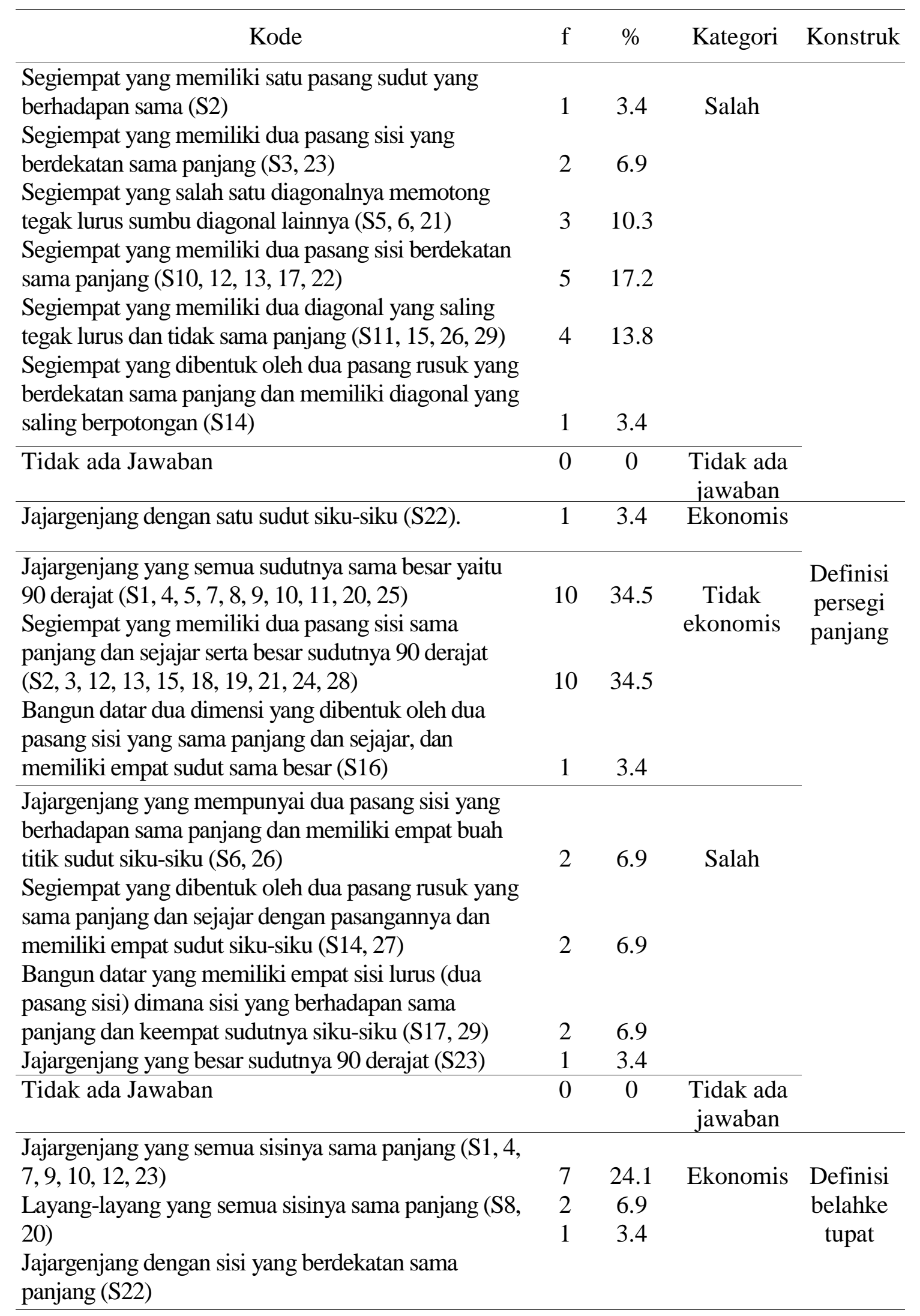




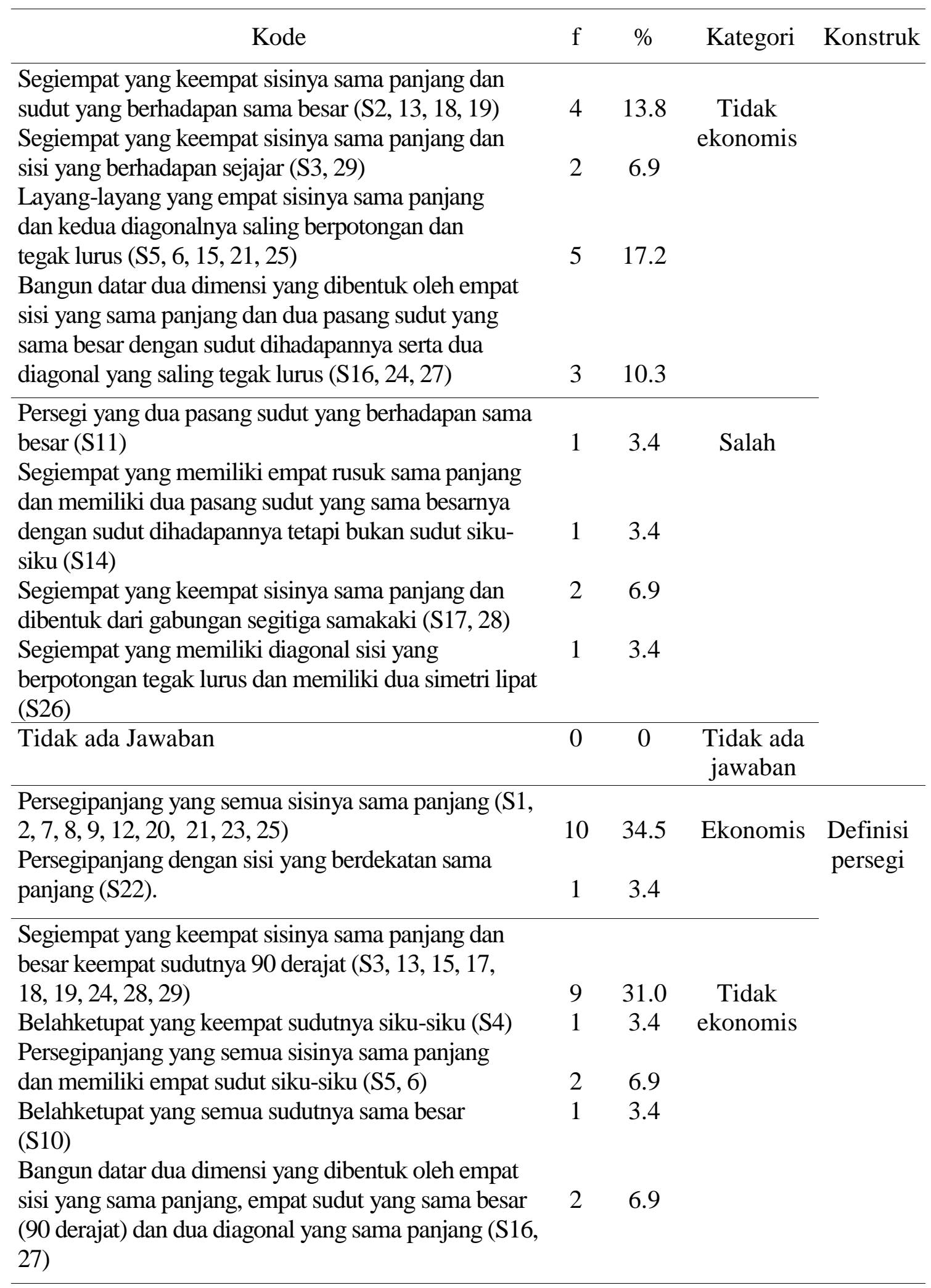




\begin{tabular}{lllll}
\hline \multicolumn{1}{c}{ Kode } & f & $\%$ & Kategori & Konstruk \\
\hline $\begin{array}{l}\text { Jajargenjang yang semua sisinya sama panjang dan } \\
\text { semua sudutnya sama besar (S11) }\end{array}$ & 1 & 3.4 & Salah & \\
$\begin{array}{l}\text { Segiempat yang dibentuk oleh empat rusuk sama } \\
\text { panjang dan empat sudut siku-siku (S14) }\end{array}$ & 1 & 3.4 & \\
$\begin{array}{l}\text { Segiempat yang memiliki empat titik sudut yang sama } \\
\text { besar dan keempat sisinya sama panjang (S26) }\end{array}$ & 1 & 3.4 & \\
\hline Tidak ada Jawaban & 0 & 0 & $\begin{array}{c}\text { Tidak ada } \\
\text { jawaban }\end{array}$ \\
\hline
\end{tabular}

\section{Jajargenjang}

Sebagaimana dikemukakan pada Tabel 2 untuk analisis vignette pertama, definisi jajargenjang adalah segiempat yang memiliki sepasang sisi sejajar dan sama panjang sebagai definisi yang ekonomis dengan persentase 3.4\%.

Ada beberapa definisi tidak ekonomis yang dikemukakan subjek. Jajargenjang adalah segiempat yang pasangan sisi berhadapan,sejajar sama panjang, dan sudut yang berhadapan sama (41.4\%). Jajargenjang adalah segiempat yang memiliki dua pasang sisi sejajar dan sama panjang (20.7\%). Jajargenjang adalah segiempat yang dua pasang sisi sejajar dan sudut yang berhadapan sama besar (13.8\%). Jajargenjang adalah segiempat yang dibentuk oleh dua pasang sisi yang sama panjang dan sejajar, dan memiliki dua pasang sudut yang sama besar dengan sudut dihadapannya $(3.4 \%)$.

Definisi yang tergolong definisi salah yang dikemukakan oleh subjek: jajargenjang adalah Segiempat yang memiliki sepasang sisi sama panjang dan sejajar (3.4\%). Jajargenjang adalah segiempat yang memiliki dua pasang sudut sama besar (3.4\%). Jajargenjang adalah segiempat yang dibentuk oleh dua pasang rusuk yang sama panjang dan sejajar dengan pasangannya, memiliki empat sudut yang bukan siku-siku (10.3\%).

\section{Trapesium}

Sementara subjek yang membuat definisi yang ekonomis untuk trapesium adalah segiempat yang memiliki sepasang sisi sejajar (44.8\%). Segiempat yang memiliki tepat sepasang sisi berhadapan sejajar (20.7\%). Segiempat dengan minimal satu pasang sisi yang sejajar (3.4\%).

Definisi yang tidak ekonomis: segiempat yang memiliki sepasang sisi yang berhadapan sejajar dan tidak sama panjang serta memiliki sisi yang lain tetapi tidak 
sejajar (10.3\%). Segiempat yang memiliki sepasang sisi yang berhadapan sejajar dan jumlah sudutnya 360 derajat $(6.9 \%)$.

Definisi yang salah: segiempat yang memiliki sepasang sisi yang sejajar dan tidak sama panjang (6.9\%). Trapesium adalah bangun datar dua dimensi yang dibentuk oleh sepasang sisi yang sejajar dan sisi lainnya sama panjang, diagonaldiagonalnya sama panjang dan sepasang sudut siku-siku (3.4\%). Trapesium adalah segiempat yang sepasang sisi yang berhadapan sama panjang (3.4\%).

\section{Layang-layang}

Tidak ada subjek yang membuat definisi ekonomis dari layang-layang. Subjek yang membuat definisi tidak ekonomis dari layang-layang: segiempat yang dua pasang sisinya yang berdekatan sama panjang dan sepasang sudut yang berhadapan sama besar yang lebih dari 90 derajat (10.3\%). Layang-layang adalah bangun datar dua dimensi yang dibentuk oleh dua pasang sisi yang sama panjang, sepasang sudut berhadapan sama besar dan dua diagonal yang saling tegak lurus dan tidak sama panjang (6.9\%). Layang-layang adalah segiempat yang memiliki dua pasang sisi sama panjang dan kedua diagonalnya saling tegak lurus (24.1\%).

Definisi yang salah oleh subjek terhadap layang-layang sangat beragam. Layang-layang didefinisikan segiempat yang memiliki satu pasang sudut yang berhadapan sama (3.4\%). Layang-layang adalah segiempat yang memiliki dua pasang sisi yang berdekatan sama panjang (6.9\%). Layang-layang adalah segiempat yang salah satu diagonalnya memotong tegak lurus sumbu diagonal lainnya (10.3\%). Layang-layang adalah segiempat yang memiliki dua pasang sisi berdekatan sama panjang (17.2). Layang-layang adalah segiempat yang memiliki dua diagonal yang saling tegak lurus dan tidak sama panjang (13.8\%). Layanglayang adalag segiempat yang dibentuk oleh dua pasang rusuk yang berdekatan sama panjang dan memiliki diagonal yang saling berpotongan (3.4\%).

\section{Persegipanjang}

Hanya $3.4 \%$ yang mendefinisikan persegipanjang dengan ekonomis: persegipanjang adalah jajargenjang dengan satu sudut siku-siku. Definisi yang tidak ekonomis: persegipanjang adalah jajargenjang yang semua sudutnya sama besar yaitu 90 derajat (34.5\%). Persegipanjang adalah segiempat yang memiliki dua pasang sisi sama panjang dan sejajar serta besar sudutnya 90 derajat (34.5\%). 
Persegipanjang adalah bangun datar dua dimensi yang dibentuk oleh dua pasang sisi yang sama panjang dan sejajar, dan memiliki empat sudut sama besar (3.4\%).

Sedangkan definisi yang salah, persegipanjang didefinisikan jajargenjang yang mempunyai dua pasang sisi yang berhadapan sama panjang dan memiliki empat buah titik sudut siku-siku (6.9\%). Persegipanjang didefinisikan segiempat yang dibentuk oleh dua pasang rusuk yang sama panjang dan sejajar dengan pasangannya dan memiliki empat sudut siku-siku (6.9\%). Persegipanjang adalah bangun datar yang memiliki empat sisi lurus (dua pasang sisi) dimana sisi yang berhadapan sama panjang dan keempat sudutnya siku-siku (6.9\%). Persegipanjang adalah jajargenjang yang besar sudutnya 90 derajat (3.4\%).

\section{Belahketupat}

Ada beberapa definisi belahketupat yang ekonomis dikemukakan oleh subjek. Belahketupat didefinisikan jajargenjang yang semua sisinya sama panjang (24.1\%). Belahketupat adalah layang-layang yang semua sisinya sama panjang (6.9\%). Belahketupat adalah jajargenjang dengan sisi yang berdekatan sama panjang $(3.4 \%)$.

Definisi yang tidak ekonomis: belahketupat adalah segiempat yang keempat sisinya sama panjang dan sudut yang berhadapan sama besar (13.8\%). Belahketupat adalah segiempat yang keempat sisinya sama panjang dan sisi yang berhadapan sejajar (6.9\%). Belahketupat didefinisikan layang-layang yang empat sisinya sama panjang dan kedua diagonalnya saling berpotongan dan tegak lurus (17.2\%). Belahketupat adalah bangun datar dua dimensi yang dibentuk oleh empat sisi yang sama panjang dan dua pasang sudut yang sama besar dengan sudut dihadapannya serta dua diagonal yang saling tegak lurus (10.3\%).

Sedangkan definisi yang salah: belahketupat didefinisikan persegi yang dua pasang sudut yang berhadapan sama besar (3.4\%). Belahketupat adalah segiempat yang memiliki empat rusuk sama panjang dan memiliki dua pasang sudut yang sama besarnya dengan sudut dihadapannya tetapi bukan sudut siku-siku (3.4\%). Belahketupat didefinisikan segiempat yang keempat sisinya sama panjang dan dibentuk dari gabungan segitiga samakaki (6.9\%). Belahketupat adalah segiempat yang memiliki diagonal sisi yang berpotongan tegak lurus dan memiliki dua simetri lipat $(3.4 \%)$. 


\section{Persegi}

Definisi ekonomis dari persegi yang dikemukakan subjek cukup beragam. Persegi adalah persegipanjang yang semua sisinya sama panjang (34.5\%). Persegi adalah persegipanjang dengan sisi yang berdekatan sama panjang (3.4\%).

Ada beberapa definisi yang tidak ekonomis yang dikemukakan oleh subjek. Persegi adalah segiempat yang keempat sisinya sama panjang dan besar keempat sudutnya 90 derajat (31.0\%). Persegi adalah belahketupat yang keempat sudutnya siku-siku (3.4\%). Persegi adalah belahketupat yang semua sudutnya sama besar (6.9\%). Persegi adalah persegipanjang yang semua sisinya sama panjang dan memiliki empat sudut siku-siku (3.4\%). Persegi adalah bangun datar dua dimensi yang dibentuk oleh empat sisi yang sama panjang, empat sudut yang sama besar (90 derajat) dan dua diagonal yang sama panjang (6.9\%).

Masih ada beberapa definisi salah yang dikemukakan oleh subjek. Persegi adalah jajargenjang yang semua sisinya sama panjang dan semua sudutnya sama besar (3.4\%). Persegi adalah segiempat yang dibentuk oleh empat rusuk sama panjang dan empat sudut siku-siku (3.4\%). Persegi adalah segiempat yang memiliki empat titik sudut yang sama besar dan keempat sisinya sama panjang (3.4\%).

Berikut kutipan wawancara peneliti dengan subjek S8 dan S1 tentang definisi dari persegi yang diberikan adalah sebagai berikut:

R: Dari ciri-ciri bangun segiempat, bangun apa yang paling dikenal ciricirinya?

S8: Kenal semua ciri-cirinya. Dari bangun segiempat, yang paling khas itu persegi. Karena banyak contoh-contoh yang berkaitan dengan persegi. Karakternya juga lebih komplit, sudah memenuhi karakter semua bangunbangun yang lain: memiliki dua pasang sisi sejajar, semua sisinya sama panjang. Hampir semua karakter segiempat yang lain itu dimiliki sama persegi.

S1: Semua ciri-ciri bangun segiempat dikenal.

$\mathrm{R}: \quad$ Apakah persegipanjang adalah jajargenjang?

S8: Iya, persegipanjang adalah jajargenjang. Karena persegipanjang memiliki sifat jajargenjang yaitu memiliki dua pasang sisi yang sejajar dan sama panjang.

S1: Persegipanjang bukan jajargenjang. Kalau persegipanjang syaratnya keempat sudutnya siku-siku sedangkan jajargenjang keempat sudutnya tidak siku-siku. Sudut yang saling berhadapan pada jajargenjang sama besar.

$\mathrm{R}: \quad$ Apakah persegi adalah persegipanjang?

S8: Iya, persegi adalah persegipanjang yang panjang dan lebarnya sama. 
S1: $\quad$ Persegi bukan persegipanjang karena kalau persegi syaratnya itu keempat sisinya harus sama panjang semua. Sedangkan persegipanjang tidak, hanya ada dua pasang yang sama panjang.

R: Apakah jajargenjang itu adalah trapesium?

S8: Iya Pak. Karena juga memiliki sepasang sisi yang sejajar.

S1: Bukan. Karena jajargenjang dua pasang sisi yang saling sejajar. Sedangkan trapesium hanya ada sepasang sisi yang saling sejajar dan sepasang sisi yang lainnya tidak sejajar

$\mathrm{R}: \quad$ Apakah persegipanjang adalah persegi?

S8: Belum tentu, karena tidak semua persegipanjang memiliki semua sisi yang sama panjang seperti yang dimiliki oleh persegi.

S1: Bukan. Karena persegipanjang, dua pasang sisi yang saling berhadapan sama panjang sedangkan pada persegi keempat sisinya sama panjang.

R: Apakah trapesium adalah jajargenjang?

S8: Belum tentu, karena trapesium tidak selalu memiliki dua pasang sisi yang sejajar.

S1: Bukan. Karena bangun trapesium berbeda dengan jajargenjang. Jajargenjang dua pasang sudut yang saling berhadapan sama besar sedangkan trapesium tidak seperti itu.

Pada vignette kedua, para mahasiswa calon guru diminta untuk membuat klasifikasi segiempat. Setelah dianalisis jawaban dari mahasiswa calon guru, ada 4 kategori yang ditemukan dalam membuat klasifikasi hirarkis lengkap, hirarkis tidak lengkap, partisional dan tidak ada jawaban.

Tabel 3. Deskripsi hasil vignette "hubungan antara jajargenjang, persegipanjang, belahketupat, persegi, trapesium, dan layang-layang?"

\begin{tabular}{llllll}
\hline Kode & $\mathrm{f}$ & $\%$ & Kategori & Konstruk \\
\hline Segiempat & 11 & 37.9 & $\begin{array}{l}\text { Hirarkis } \\
\text { lengkap }\end{array}$ & $\begin{array}{l}\text { Klasifikasi } \\
\text { inklusif }\end{array}$ \\
\hline
\end{tabular}

$(\mathrm{S} 5,6,9,10,15,16,22,23,24,25,28)$ 


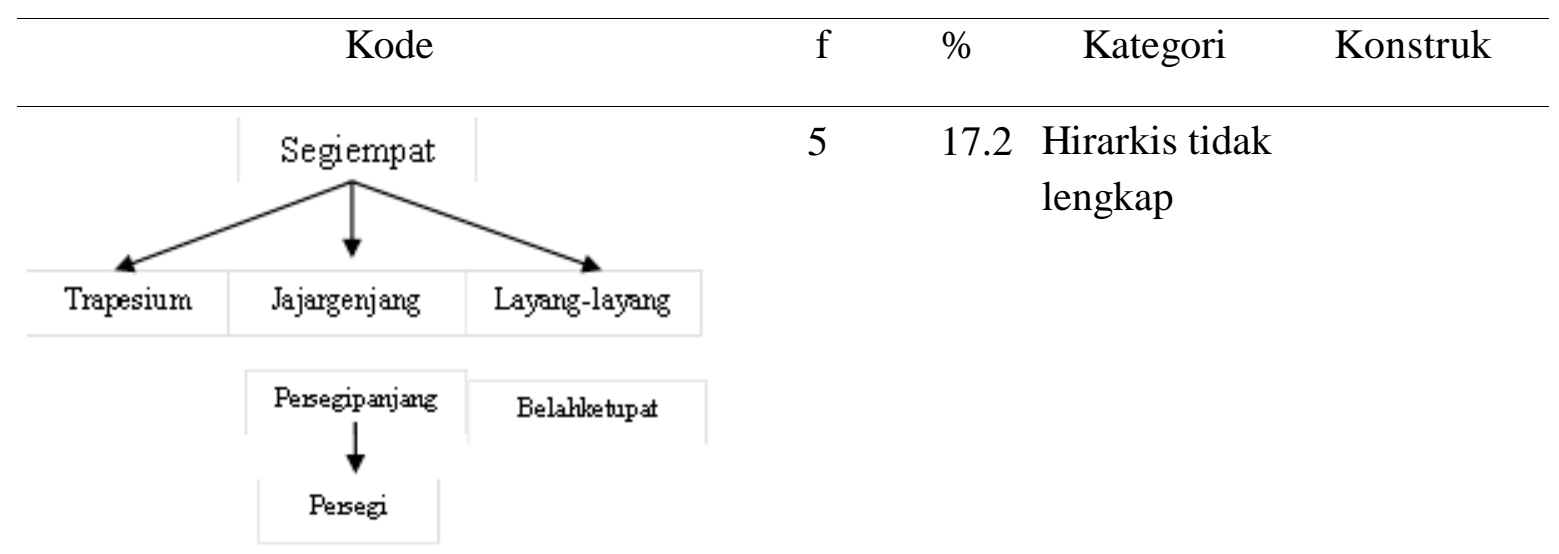

$(\mathrm{S} 2,3,13,26,29)$

$5 \quad 17.2 \quad$ Hirarkis tidak lengkap

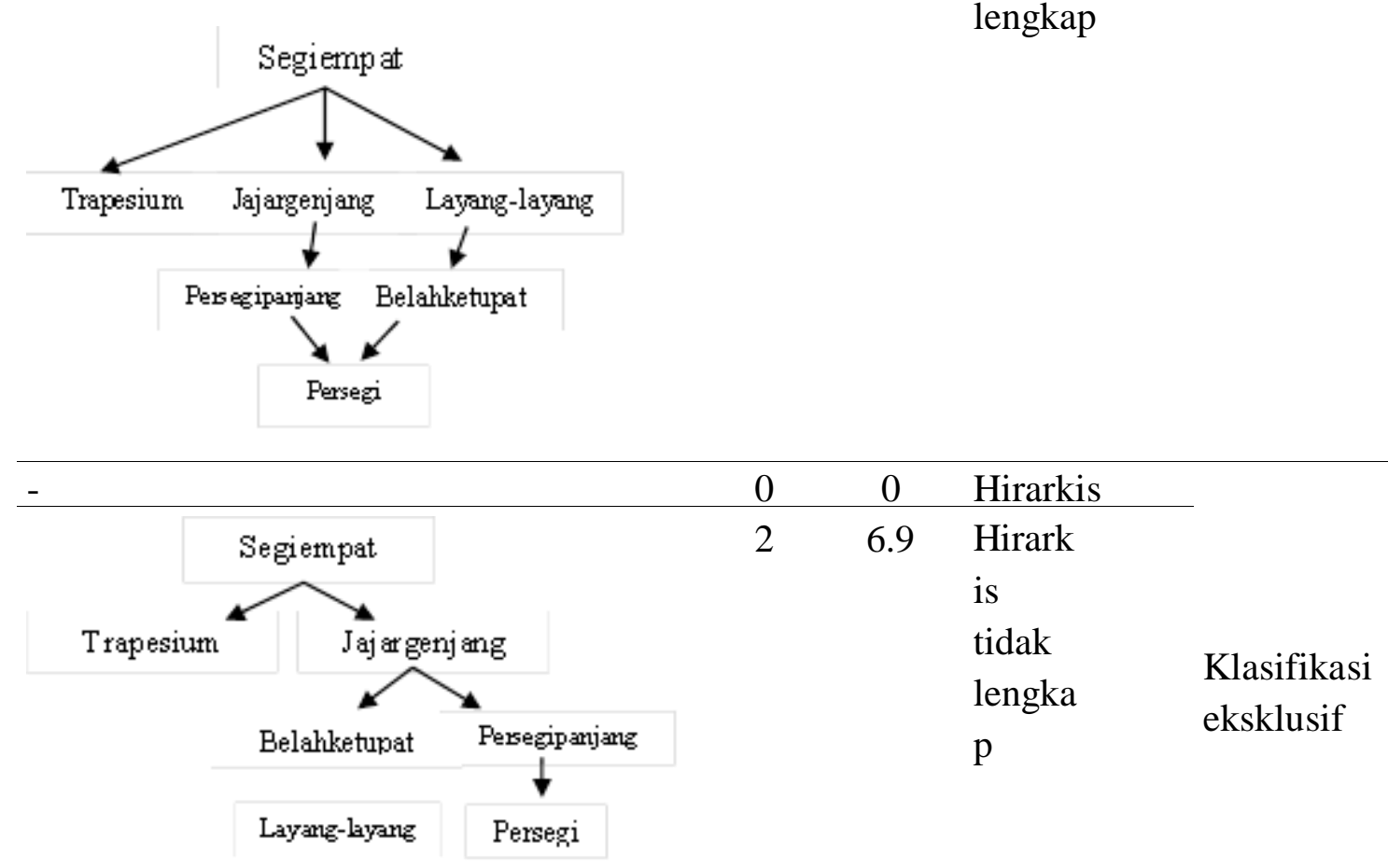

$(\mathrm{S} 1,4)$

\begin{tabular}{lccc}
\hline$(\mathrm{S} 7,11,12,14,19,27)$ & 6 & 20.7 & Partisional \\
\hline- & 0 & 0 & Tidak ada \\
\hline
\end{tabular}

Seperti yang ditunjukkan pada Tabel 3 untuk analisis vignette kedua, klasifikasi inklusif-lengkap meliputi subjek S5, 6, 9, 10, 15, 16, 22, 23, 24, 25, 28), segiempat meliputi trapesium, jajargenjang, layang-layang, persegipanjang, belahketupat dan persegi. Jajargenjang terbagi atas belahketupat persegipanjang dan persegi. Persegi adalah bagian dari persegipanjang, persegi juga bagian dari belahketupat. Hasil ini 
menggambarkan bahwa calon guru mendefinisikan trapesium sebagai segiempat yang mempunyai tepat sepasang sisi sejajar, sehingga hubungan trapesium dengan segiempat lainnya saling lepas (Soedjadi, 2005; Popovic, 2012; Budiarto, 2017).

Untuk klasifikasi inklusif-tidak lengkap oleh subjek S2, 3, 13, 26, 29), segiempat meliputi trapesium, jajargenjang, layang-layang, persegipanjang, belahketupat dan persegi. Jajargenjang terbagi atas belahketupat dan persegipanjang. Belahketupat adalah bagian dari layang-layang, serta persegi adalah bagian dari persegipanjang.

Selain itu, subjek S8, 17, 18, 20, 21), segiempat meliputi trapesium, jajargenjang, layang-layang, persegipanjang, belahketupat dan persegi. Jajargenjang terbagi atas belahketupat dan persegipanjang. Layang-layang terbagi atas belahketupat dan persegi. Persegi adalah bagian dari persegipanjang dan belahketupat.

Sedangkan, klasifikasi eksklusif, subjek S1 dan S4; segiempat meliputi trapesium, jajargenjang, layang-layang, persegipanjang, belahketupat dan persegi. Jajargenjang terbagi atas belahketupat persegipanjang persegi dan layang-layang. Persegi adalah bagian dari persegipanjang, sedangkan layang-layang bagian dari belahketupat. Hal ini menunjukkan subjek mengalami sedikit miskonsepsi disebabkan subjek mengklasifikasi layang-layang bagian dari belahketupat.

Dari hasil vignette pertama dan vignette kedua, selanjutnya dilakukan analisis isi untuk mengungkap tingkat pemahaman konseptual mahasiswa calon guru terhadap segiempat. Setelah dilakukan analisis isi, selanjutnya ditentukan bagaimana tingkat pemahaman konseptual calon guru terhadap konsep segiempat. Menurut Sahidin (2019b: 184) ada empat kategori pemahaman konseptual meliputi: mature-conceptual, developing-conceptual, nä̈ve-conceptual dan not developconceptual.

Seperti dapat dilihat dari Tabel 3, ditemukan bahwa persentase calon guru yang mature-conceptual adalah 82\%. Ditemukan bahwa persentase calon guru yang developing-conceptual adalah 16\%; naïve-conceptual $=10 \%$ dan tingkat not develop-conceptual adalah $2 \%$. 
Tabel 4. Tingkat pemahaman konseptual terhadap materi segiempat

\begin{tabular}{lccll}
\hline \multicolumn{1}{c}{ Kode } & $\mathrm{f}$ & $\%$ & \multicolumn{1}{c}{ Kategori } & Konstruk \\
\hline Trapesium & 20 & $69.0 \%$ & Mature-conceptual & \\
Persegi & 11 & $37.9 \%$ & & \\
Belahketupat & 10 & $34.5 \%$ & & \\
Jajargenjang & 1 & $3.4 \%$ & Rata-rata $=7.2 \%$ & \\
Persegipanjang & 1 & $3.4 \%$ & & \\
Layang-layang & 0 & $0.0 \%$ & & \\
Trapesium & 5 & $17.2 \%$ & Developing- & Tingkat \\
Persegi & 15 & $51.7 \%$ & conceptual & konseptual \\
Belahketupat & 14 & $48.3 \%$ & & \\
Jajargenjang & 23 & $79.3 \%$ & & \\
Persegipanjang & 21 & $72.4 \%$ & Rata-rata $=15.0 \%$ & \\
Layang-layang & 12 & $41.4 \%$ & & \\
Trapesium & 4 & $13.8 \%$ & Nä̈ve-conceptual & \\
Persegi & 3 & $10.3 \%$ & & \\
Belahketupat & 5 & $17.2 \%$ & & \\
Jajargenjang & 5 & $17.2 \%$ & Rata-rata $=6.5 \%$ & \\
Persegipanjang & 7 & $24.1 \%$ & & \\
Layang-layang & 15 & $51.7 \%$ & & \\
\hline Trapesium & 0 & $0.0 \%$ & Not develop- & \\
Persegi & 0 & $0.0 \%$ & conceptual & \\
Belahketupat & 0 & $0.0 \%$ & & \\
Jajargenjang & 0 & $0.0 \%$ & & \\
Persegipanjang & 0 & $0.0 \%$ & Rata-rata = 0.0\% & \\
Layang-layang & 0 & $0.0 \%$ & & \\
\hline & & & & \\
\end{tabular}

Dari Tabel-4 diperoleh bahwa tingkat pemahaman konseptual calon guru: mature-conceptual (7.2\%); developing-conceptual (15.0\%); naïve-conceptual (6.5\%) sedangkan not develop-conceptual (0.0\%).

\section{Kesimpulan}

Dari hasil dan pembahasan diperoleh tiga kesimpulan. Pertama, calon guru matematika mengalami kesulitan dalam mendefinisikan segiempat dari vignette yang diberikan, terutama layang-layang, jajargenjang dan persegipanjang. Hal ini karena calon guru masih dipengaruhi oleh bentuk gambar bangun-bangun geometri. Temuan ini dapat timbul sebagai hasil dari metode pembelajaran yang umum digunakan dalam pembelajaran matematika. Kedua, dalam mengklasifikasi atau membuat hubungan antar segiempat, calon guru cukup baik meskipun ada beberapa calon guru yang mengalami kesulitan mengklasifikasi persegi dan belahketupat 
secara tepat. Ketiga, sebagian besar calon guru matematika memiliki tingkat pemahaman developing-konseptual.

\section{Daftar Pustaka}

Ball D., L, Lubienski S.,T. \& Mewborn D., S. (2001). Research on teaching mathematics: The unsolved problem of teachers' mathematical knowledge. In Richardson V (Ed.), Handbook of research on teaching (pp. 433-456) 4th edn. New York: Macmillian

Barrantes, M. \& Blanco, L., J. (2006). A study of prospective primary teachers' conceptions of teaching and learning school geometry. Journal of Mathematics Teacher Education, 9, 411-436.

Budiarto, M.T., Khabibah, S., \& Setianingsih, R., (2017). Construction of High School Students' Abstraction Levels in Understanding the Concept of Quadrilaterals. International Education Studies; Vol. 10, No. 2. Canadian Center of Science and Education, ISSN 1913-9020 E-ISSN 1913-9039

Büyüköztürk, Ş., Kilic Çakmak, E., Erkan Akgün, O., Karadeniz, S., \& Demirel, F. (2009). Bilimsel Arastirma Yöntemleri. Ankara: Pegem Akademi.

Çepni, S. (2018). Arastirma telah proje Çalışmalarına Giriş. Trabzon: Celepler Matbaacilik.

Chick, L. (2003). Pre-Service Teachers' Explanation of Two Mathematical Concepts. Makalah disajikan pada Konferensi Tahunan International Education Research. Australian Association for Research in Education.

De Villiers, M. (1998, July). To teach definitions in geometry or teach to define?. In PME Conference (Vol. 2, pp. 2-248).

Fujita, T., \& Jones, K. (2007). Learners' Understanding of the Definitions and Hierarchical Classification of Quadrilaterals: Towards a Theoretical Framing. Research in Mathematics Education, 9(1), 3-20.

Fujita, T. (2012). Learners' level of understanding of the inclusion relations of quadrilaterals and prototype phenomenon. The Journal of Mathematical Behavior, 31(1), 60-72.

Fuys, D., Geddes, D., \& Tischler, R. (1988). The Van Hiele model of thinking in geometry among adolescents. Journal for Research in Mathematics Education. Monograph, 3. Reston, VA: National Council of Teachers of Mathematics.

Govender \& De Villiers. (2002). Constructive Evaluation of Definitions in a Sketcpad Context. AMESA Durban South Africa. 
Günhan, B. C. (2014). An Investigation of Pre-Service Elementary School Teachers' Knowledge Concerning Quadrilaterals. Çukurova University. Faculty of Education Journal, 43(2), 137.

Hershkowitz, R., \& Vinner, S. (1984). Children's concepts in elementary geometry. A reflection of teacher's concepts?. In B. Southwell R. Eyland, M. Cooper, J. Conroy, \& K. Collis (Eds.), Proceedings of the 8th PME International Conference (pp. 63-69). Darlinghurst, Australia: Mathematical Association of New South Wales.

Mayberry, J. (1983). The van Hiele level of geometric thought in undergraduate pre-service teachers. Journal for Research in Mathematics Education, 14, 58-69.

McCammon, J. E. (2018). Preservice Teachers' Understanding Of Geometric Definitions And Their Use In The Concept Of Special Quadrilaterals.

Miles, MB, \& Huberman, AM (1994). Analisis data kualitatif: Sebuah Buku Sumber diperluas. (2nd ed.). California: SAGE Publications.

Popovic, G. (2012). Who is this trapezoid, anyway? Mathematics Teaching in the Middle School, 18(4), 196-199.

Sahidin, L., Fuad, Y., \& Budiarto, M. T. (2019a). Teachers content knowledge in generalizing mind maps of quadrilateral. In Journal of Physics: Conference Series (Vol. 1157, No. 4, p. 042091). IOP Publishing.

Sahidin, Latief. (2019b). Mathematical Knowledge for Teaching-Based Conceptual dalam Konten Geometri. Kendari: Universitas Halu Oleo Press.

Soedjadi, R. (1995). Memantapkan Matematika Sekolah sebagai Wahana Pendidikan dan Pembudayaan Penalaran. Makalah disampaikan pada Seminar Nasional Pendidikan Matematika FPMIPA IKIP Medan, Medan.

Okazaki, M., \& Fujita, T. (2007, July). Prototype phenomena and common cognitive paths in the understanding of the inclusion relations between quadrilaterals in Japan and Scotland. In Proceedings of the 31st Conference of the International Group for the Psychology of Mathematics Education (Vol. 4, pp. 41-48).

Ozdemir Erdogan, E., \& Dur, Z. (2014). Preservice mathematics teachers' personal figural concepts and classifications about quadrilaterals. Australian Journal of Teacher Education, 39(6), 8.

Türnüklü, E., Akkaş, E. N., \& Alaylı, F. G. (2013, February). Mathematics teachers' perceptions of quadrilaterals and understanding the inclusion relations. In Proceedings of the Eighth Congress of the European Society for Research in Mathematics Education (pp. 705-714). 
Ulger, T. K., \& Broutin, M. S. T. (2017). Pre-Service Mathematics Teachers' Understanding of Quadrilaterals and the Internal Relationships between Quadrilaterals: The Case of Parallelograms. European Journal of Educational Research, 6(3), 331-345.

Yildirim, A., \& Simsek, H. (2008). Sosyal bilimlerde NITEL Arastirma yöntemleri. Ankara: Seçkin Yayincilik. 